\title{
Comparative Study of PI, Fuzzy and Fuzzy tuned PI Controllers for Single-Phase AC-DC Three-Level Converter
}

\author{
Gnanavadivel $\mathbf{J}^{\dagger}$, Senthil Kumar $\mathrm{N}^{*}$ and Yogalakshmi $\mathrm{P}^{*}$
}

\begin{abstract}
This paper presents the design of closed loop controllers operating a single-phase AC-DC three-level converter for improving power quality at AC mains. Closed loop inhibits outer voltage controller and inner current controller. Simulations of three level converter with three different voltage and current controller combinations such as PI-Hysteresis, Fuzzy-Hysteresis and Fuzzy tuned PIHysteresis are carried out in MATLAB/Simulink. Performance parameters such as input power factor and source current total harmonic distortion (THD) are considered for comparison of the three controller combinations. The fuzzy-tuned PI voltage controller with hysteresis current controller combination provides a better result, with a source-current THD of $0.93 \%$ and unity power factor without any source side filter for the three level converter. For load variations of $25 \%$ to $100 \%$, a THD of less than $5 \%$ is obtained with a maximum value of only $1.67 \%$. Finally, the fuzzy-tuned PI voltage with hysteresis controller combination is implemented in a Xilinx Spartan-6 XC6SLX25 FPGA board for experimental validation of power quality enhancement. A prototype $100 \mathrm{~W}, 0-24-48 \mathrm{~V}$ as output converter is considered for the testing of controller performance. A source-current THD of $1.351 \%$ is obtained in the experimental study with a power factor near unity. For load variations of $25 \%$ to $100 \%$, the THD is found to be less than $5 \%$, with a maximum value of only $2.698 \%$ in the experimental setup which matches with the simulation results.
\end{abstract}

Keywords: Fuzzy Logic Controller (FLC), Fuzzy-Tuned PI (Fuzzy PI), PI, Hysteresis Current Controller (HCC), Power Factor, Total Harmonic Distortion (THD), Three-Level converter

\section{Introduction}

Diode-based bridge rectifiers are commonly used power supply. The low input power factor and very high source current harmonics are found to be main drawbacks of using classical diode based rectifier and thyristor based rectifier configurations. These issues are resolved by the usage of series choke combination containing capacitors and diodes [1]. By introducing an inductor on AC source side, the current waveform can be improved yet the input power factor gets affected [2]. In order to reduce current stresses in rectifier and to improve the power factor, a passive wave shaping method is employed [3]. The recommended limits of harmonics in the input power supply are well described in IEEE 519 and IEC 1000-3-2 standards [4-5].

With the ever-increasing use of power electronic products, power factor correction (PFC) becomes mandatory. Having this in mind, opt choices are less cost-small size-high efficiency power converters [6]. Shaping of input current waveform and regulation of output voltage are the main functions of power factor correction converter. With continuous source current, boost converters have been

$\dagger \quad$ Corresponding Author: Dept. of Electrical and Electronics Engineering, Mepco Schlenk Engineering College, India. (jgvadivel@gmail.com)

* Dept. of Electrical and Electronics Engineering, Mepco Schlenk

Engineering College, India. (yogalakshmisomu@gmail.com,

nsk vnr@yahoo.com)

Received: June 21, 2015; Accepted: April 27, 2016 greatly employed in AC-DC converters for attaining desired PFC function and source current harmonic reduction [7]. Digital current control method, implemented by accurate mode boundary detection using exact estimate of inductance is quite helpful [8]. Sensing of output voltage is needed for outer voltage loop in order to regulate the derived output. It is also necessary to sense the input voltage for reference current generation and for feed forward terms [9]. Converter's performance sensitivity to parameter variations and uncertainties can be greatly increased with the help of feed forward control [10]. Multiloop control with compensation loops is most effective for motor drive applications for speed regulation with enhanced PFC.

As for the boost converter, the single switch needs to tolerate the overall output voltage when the switch blocks the signal. Hence multilevel converters with power switches capable of managing high voltage stress are preferred for high voltage and high power applications [11]. Acoustic noise reduction with switch mode rectifier incorporating current controlled PWM methods by arbitrarily varying hysteresis band is used for PMSM drive [12].

To achieve high step-up voltage gain, coupled inductors and voltage doubler circuits are merged in the DC-DC converter [13]. Power semiconductor switches of eight numbers are major disadvantage for classical single phase 
three level rectifier. Hence a single phase AC-DC three level converter employing just two number of power semiconductor switches are preferred [14]. Capacitors connected across each switch ensure that each switch is subjected to tolerate only half the output voltage. Also three level of inductor voltage provide assurance for lower amount of ripple current in inductor. Thus three level converters are mostly engaged in DC-DC voltage conversions with high voltage ratio likely in fuel cell applications [15]. Three level DC-DC converters with wide range of input are most appropriate for fuel cell applications [16]. Three level boosting MPPT control technique is adopted in photovoltaic systems for improving power conversion efficiency by reducing reverse recovery losses of diodes [17].

Multi-level converters are the most preferable choice for wind energy systems to minimize the cost, size and complexity of the systems compared to two-level boost converters [18]. The supreme characteristics of three level converter are reduced voltage stress, small inductor current ripples and very low switching loss [19]. Well designed PWM integrated with three level delta converter has capability to reduce source current THD with less current ripples [20]. For achieving voltage balance of capacitors in three level converter, voltage compensators are employed with PWM control [21]. Source current THD of $6 \%$ is achieved by implementing hysteresis control along with capacitor compensator and power estimator blocks [22]. A multiloop interleaved technique is proposed for minimizing the number of sensing parameters in three level converter [23].

Midpoint converter SRM performance is enhanced by the use of a single-phase three-level PFC rectifier. Buck converter fed DC drive with PI, fuzzy, ANN controllers are engaged for controlling speed of DC drive [25]. An appropriate modeling of fuzzy logic controller gives guarantee for controlling non-linearities own by DC motor [26]. PI and fuzzy logic controller help to regulate the DC link bus voltage at predefined level. Superior fuzzy controller proves its excellence during transience disturbances. DC-DC converters adapting FLCs are used in two level and three level converters [27-30]. Fuzzy-tuned PI controllers are used in various DC-DC converters for the optimization of errors and reactive power control [31-35].

This paper proposes a fuzzy-tuned PI voltage control for a single-phase three-level AC-DC converter. However, three control strategies - a PI voltage controller with a hysteresis current controller, a fuzzy logic voltage controller with a hysteresis current controller and a fuzzy-tuned PI voltage controller with a hysteresis current controller are implemented for the converter with the objective of drawing a pure sinusoidal input current with low total harmonic distortion and high power factor.

The performance of the proposed fuzzy-tuned PI control scheme is also compared with the PI and fuzzy logic control schemes. The three level AC-DC converters can be used as front stages for battery chargers, uninterrupted power supplies and three-level inverter applications. This study suggests that an improved fuzzy-tuned PI voltage controller with a hysteresis control method as compared to [23-24] can achieve a lower source current total harmonic distortion of $0.93 \%$ in simulations and a THD of $1.351 \%$ in experiments with a power factor closer to unity. In addition, the total harmonic distortion achieved is lower than the IEEE-519 standard limit.

\section{Modeling of AC-DC Three-Level Converter}

Fig. 1 shows the single-phase AC-DC three-level converter. This circuit strategy consists of a single-phase diode bridge rectifier, two power switching devices, one inductor, two fast-recovery diodes and two DC capacitors. An inductor $\left(\mathrm{L}_{\mathrm{b}}\right)$ is helpful for minimization of ripple current. Voltage rating of power semiconductor elements can be deduced to nearly half the voltage of DC bus. The inductor boost volume is one quarter of the conventional boost converter. The single-phase three-level rectifier can be analyzed in its four operating modes according to the states of two power semiconductor switches $\mathrm{S}_{1}$ and $\mathrm{S}_{2}$.

Based on the circuit diagram, when $\mathrm{S}_{1}$ and $\mathrm{S}_{2}$ are $\mathrm{ON}$, the modeling equations are

$$
\begin{gathered}
\left|v_{s}\right|=L_{b} \frac{d i_{L}}{d t} \\
C_{1} \frac{d v_{1}}{d t}=-\frac{v_{0}}{R} \\
C_{2} \frac{d v_{2}}{d t}=-\frac{v_{0}}{R}
\end{gathered}
$$

Based on the circuit diagram, when $\mathrm{S}_{1}$ is $\mathrm{ON}$ and $\mathrm{S}_{2}$ is $\mathrm{OFF}$, the modeling equations are

$$
\begin{gathered}
L_{b} \frac{d i_{L}}{d t}=v_{s}-\frac{v_{0}}{2} \\
C_{1} \frac{d v_{1}}{d t}=-\frac{v_{0}}{R} \\
C_{2} \frac{d v_{2}}{d t}=i_{L}-\frac{v_{0}}{R}
\end{gathered}
$$

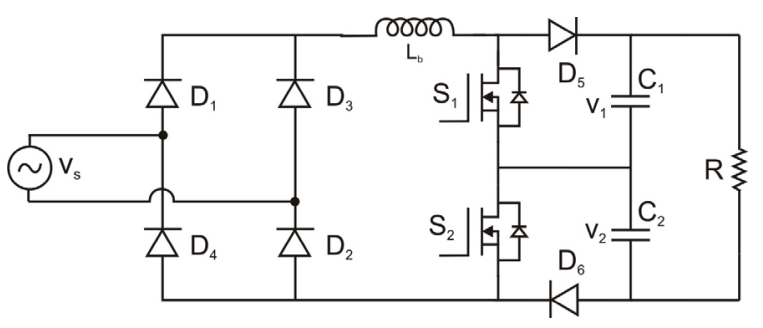

Fig. 1. Circuit configuration of single-phase AC-DC threelevel converter 
Based on the circuit diagram, when $S_{1}$ is OFF and $S_{2}$ is $\mathrm{ON}$, the modeling equations are

$$
\begin{gathered}
L_{b} \frac{d i_{L}}{d t}=v_{s}-\frac{v_{0}}{2} \\
C_{1} \frac{d v_{1}}{d t}=i_{L}-\frac{v_{0}}{R} \\
C_{2} \frac{d v_{2}}{d t}=-\frac{v_{0}}{R}
\end{gathered}
$$

Based on the circuit diagram, when $\mathrm{S}_{1}$ and $\mathrm{S}_{2}$ are OFF, the modeling equations are

$$
\begin{gathered}
L_{b} \frac{d i_{L}}{d t}=v_{s}-v_{0} \\
C_{1} \frac{d v_{1}}{d t}=i_{L}-\frac{v_{0}}{R} \\
C_{2} \frac{d v_{2}}{d t}=i_{L}-\frac{v_{0}}{R}
\end{gathered}
$$

Averaging the above equations over one switching period, we get

$$
\begin{gathered}
L_{b} \frac{d i_{L}}{d t}=v_{s}-v_{0}\left(1-d_{1}-\frac{d_{2}}{2}\right) \\
C_{1} \frac{d v_{1}}{d t}=i_{L}\left(1-d_{1}-\frac{d_{2}}{2}\right)-\frac{v_{0}}{R} \\
C_{1} \frac{d v_{2}}{d t}=i_{L}\left(1-d_{1}-\frac{d_{2}}{2}\right)-\frac{v_{0}}{R}
\end{gathered}
$$

where $d_{1}$ is the duty cycle of switch $S_{1}$ and $d_{2}$ is the duty cycle of switch $S_{2}$. By adjusting the averaged equations, we can assume that

$$
\begin{array}{lll}
v_{s}=V_{s}+\tilde{v}_{s} & v_{1}=V_{1}+\tilde{v}_{1} & v_{2}=V_{2}+\tilde{v}_{2} \\
i_{L}=I_{L}+\tilde{i}_{L} & d=D+\tilde{d} & d=d_{1}=0.5 d_{2}
\end{array}
$$

Upon simplification, we can assign transfer functions of the three-level converters as

$$
\frac{\tilde{v}_{0}(s)}{\tilde{d}(s)}=\frac{v_{0}(1-D)-s L_{b} I_{L}}{s^{2} L_{b} C+\frac{s L_{b}}{R}+(1-D)^{2}}
$$

\subsection{Design equations}

The Boost Inductor:

$$
L_{b}=\frac{v_{o}}{4 f_{s} \Delta I}
$$

where $\mathrm{V}_{\mathrm{o}}$ is the output voltage,

$\Delta I$ is the inductor current ripple and

$f_{s}$ is the switching frequency.

DC Link Capacitor:

$$
C_{1}=C_{2}=\frac{I_{o}}{2 \omega \Delta V_{1}}
$$

where $\Delta V_{1}$ is the ripple voltage across the capacitor,

$\omega$ is the angular frequency of the supply voltage and $I_{0}$ is the load current.

By substituting the values from Table 1 into Eq. (6),

$$
\frac{\tilde{\mathrm{v}}_{\mathrm{o}}(\mathrm{s})}{\tilde{\mathrm{d}}(\mathrm{s})}=\frac{32.16-11.1 \times 10^{-3} \mathrm{~s}}{2.1 \times 10^{-5} \mathrm{~s}^{2}+0.13 \times 10^{-3} \mathrm{~s}+0.4489}
$$

Table 1. Design specifications and circuit parameters

\begin{tabular}{c|c|c}
\hline S. No & Parameter & Specification \\
\hline 1 & Input line voltage $\left(\mathrm{V}_{\mathrm{s}}\right)$ & $28 \mathrm{~V}$ \\
\hline 2 & Output voltage & $48 \mathrm{~V}$ \\
\hline 3 & Output power & $100 \mathrm{~W}$ \\
\hline 4 & Switching frequency $\left(\mathrm{f}_{\mathrm{s}}\right)$ & $10 \mathrm{kHz}$ \\
\hline 5 & Duty cycle $(\mathrm{D})$ & 0.33 \\
\hline 6 & Line frequency & $50 \mathrm{~Hz}$ \\
\hline 7 & Boost inductor $\left(\mathrm{L}_{\mathrm{b}}\right)$ & $3 \mathrm{mH}$ \\
\hline 8 & Capacitance $\mathrm{C}_{1}=\mathrm{C}_{2}$ & $7000 \mu \mathrm{F}$ \\
\hline 9 & Load resistance & $23 \Omega$ \\
\hline
\end{tabular}

\section{Design of controllers}

The proposed block diagram of the single-phase AC-DC three-level converter is shown in Fig. 2. This system consists of a three-level AC-DC converter, a voltage controller, a phase-locked loop and a current controller. The proposed closed-loop control has two loops: an outer voltage control loop and an inner current loop. In the outer voltage control loop, the converter output voltage $V_{d}$ is

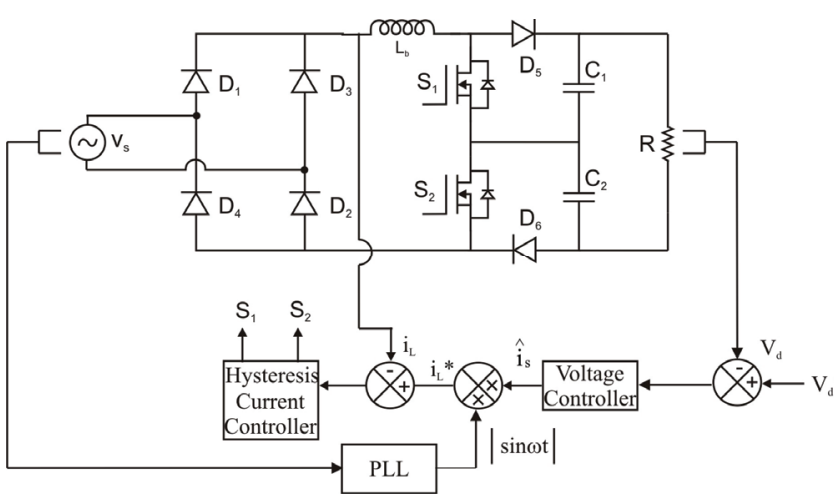

Fig. 2. Proposed block diagram of single-phase AC-DC multi-level converter 
sensed and compared with the reference voltage $V_{d}$. After comparison, an error signal is fed to the voltage controller. The supply voltage is processed by the phase-locked loop in order to produce an absolute value of sinct. The voltage controller output and the absolute value of sinct are used to obtain the amplitude of the reference inductor current $\mathrm{i}_{\mathrm{L}}{ }^{*}$. This reference inductor current is compared with the actual inductor current $i_{L}$. After comparison, an error signal is fed to the inner current control loop. A control signal thus obtained from the current controller governs the switching times of switch $\left(\mathrm{S}_{1}\right)$ and the same control signal with predefined delay takes care of switching times of switch $\left(\mathrm{S}_{2}\right)$.

\subsection{Design of PI voltage controller}

The PI controller takes into account the desired output of the converter to produce a control signal that is necessary to reduce the error signal to approximately zero. A proportional controller gain $\left(\mathrm{K}_{\mathrm{p}}\right)$ has the effect of reducing the rise time and does not eliminate the steady state error. An integral control gain $\left(\mathrm{K}_{\mathrm{i}}\right)$ has the effect of eliminating the steady state error but worsens the transient response. The error voltage obtained from the comparison of the reference output voltage and the actual output voltage is fed into the PI voltage controller in order to produce the peak value of the input current. Proportional gain and integral gain values are obtained from the transfer function of the three-level boost converter by using MATLAB auto tuning. These values are $\mathrm{K}_{\mathrm{p}}=0.1$ and $\mathrm{K}_{\mathrm{i}}=4$. This PI controller is used in the voltage loop for regulating the desired voltage.

\subsection{Design of fuzzy logic voltage controller}

Table 2 shows the fuzzy control rules. Two input variables (error and change in error) and one output variable (controlled voltage signal) are used in the design the fuzzy logic controller. Fig. 3(a) shows the membership functions for input 1 (error), input 2 (change in error) and output (control voltage signal). The triangular membership functions for the input and output variables are designed such that converter performance is improved. The centroid method is used for defuzzification. The triangular membership function is formed using straight lines. Thereby, they are simple and easy to implement in fuzzy control [36].

A fuzzy logic controller is proposed to handle the nonlinear properties of the single-phase AC-DC three-level converter under variable operating conditions. The fuzzy logic controller is used as a voltage controller. The fuzzy logic controller output and the absolute value of sinwt are used to generate the reference inductor current. The reference inductor current is compared with the actual inductor current. The calculated error in the inductor current is given as the input to the hysteresis controller. The fuzzy logic controller is used as a voltage regulator
Table 2. Fuzzy control rules

\begin{tabular}{c|c|c|c|c|c|c|c}
\hline CE & NB & NM & NS & ZE & PS & PM & PB \\
\hline NB & ZE & PS & PM & PB & PB & PB & PB \\
\hline NM & NS & ZE & PS & PM & PB & PB & PB \\
\hline NS & NM & NS & ZE & PS & PM & PB & PB \\
\hline ZE & NB & NM & NS & ZE & PS & PM & PB \\
\hline PS & NB & NB & NM & NS & ZE & PS & PM \\
\hline PM & NB & NB & NB & NM & NS & ZE & PS \\
\hline PB & NB & NB & NB & NB & NM & NS & ZE \\
\hline
\end{tabular}

NB-Negative Big; NM-Negative Medium; NS-Negative Small Z-Zero; PS-Positive Small; PM-Positive Medium; PB-Positive Big.
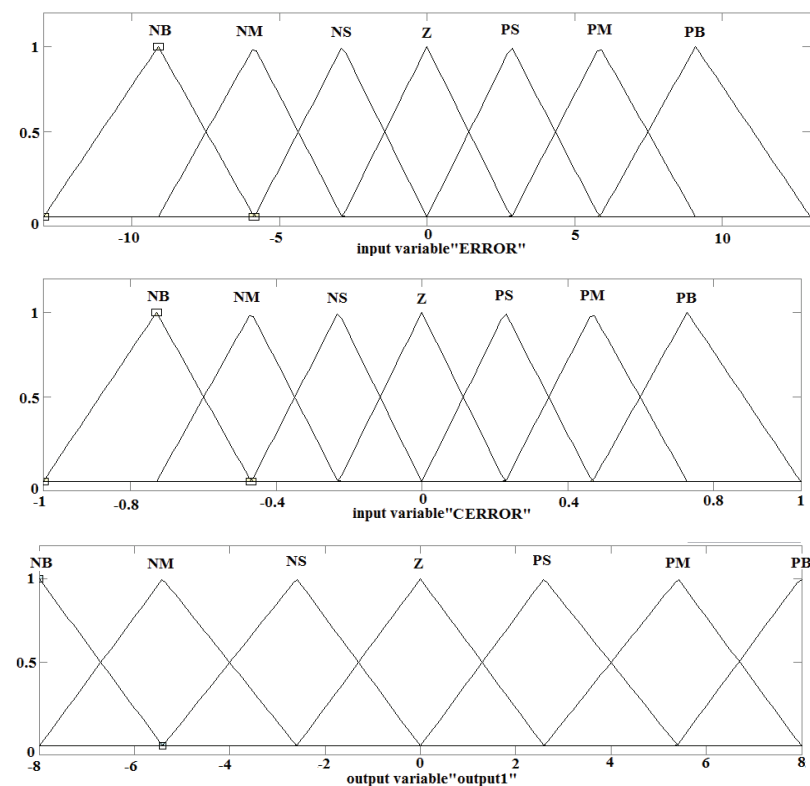

Fig. 3. (a) The membership functions for input 1 (error), input 2 (change in error) and output (control current signal)

that takes two inputs - the output voltage error and the integral of the voltage error - and outputs the reduction of error. A Mamdani-type fuzzy inference system is enabled.

\subsection{Design of fuzzy-tuned PI voltage controller}

A fuzzy-tuned PI control method is an improved method of controlling multifarious and imprecise model systems; it can provide efficient control in addition to fuzzy control robustness. A self-tuning fuzzy PI controller is the combination of a classical PI and a fuzzy controller. The goal is to set fuzzy rules that make the PI controller more suitable for an industrial process with different degrees of nonlinearity and parameter variations. The PI parameters are calculated out according to rules in the fuzzy controller. In this way, the parameters can be incessantly updated according to errors and derivatives.

In this manuscript, fuzzy tuned PI controller is implemented in a three level boost converter which provides better regulation of output voltage in addition to 
i. Structure of fuzzy-tuned PI controller

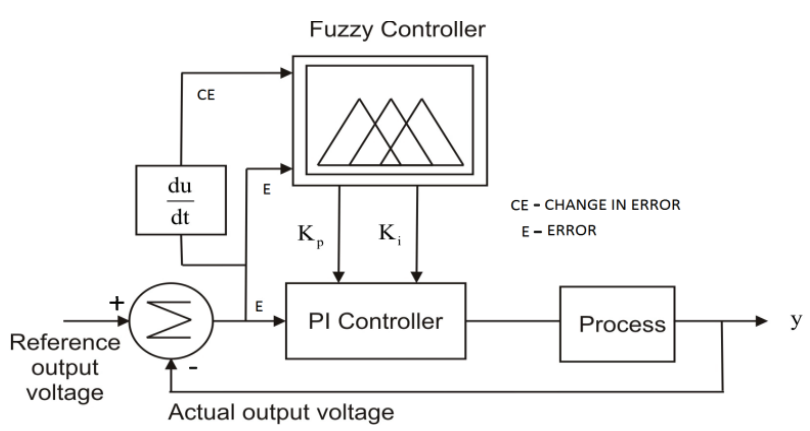

Fig. 3. (b) Structure of fuzzy-tuned PI controller

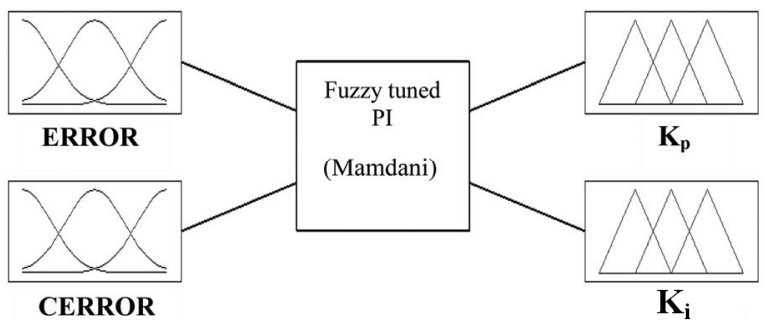

Fig. 3. (c) Membership functions

enhancement of power quality at AC mains. The fuzzy PI controller is used to regulate the DC output voltage of the converter, where the gain of the controller is adjusted adaptively. The control algorithm effectively improves the power quality by reducing the THD of the supply current and simultaneously adjusting the power factor to near unity. The ability of Fuzzy PI controllers to respond to indeterminate, unstable and time varying systems proves its prominent self tuning capability. Fuzzy PI controllers provide a promising option for industrial applications with many desirable features.

The fuzzy logic controller accompanied with PI controller provide proper fine tuning of gain constants of PI controller, as shown in Fig. 3(b). Fuzzy controller is fed with error and change in error signals as inputs. The fuzzy inference engine generates the output signals as $\mathrm{K}_{\mathrm{p}}$ and $\mathrm{K}_{\mathrm{i}}$ based on rule based membership functions after processing the inputs (E and CE). Fuzzy tuned PI doesn't need accurate mathematical model of the system, it handles and it can also easily tunes the gain values for proper operation of PI control. This control can be quite helpful for complex systems where the mathematical modeling is tedious and difficult to achieve.

Fig. 3(c) shows the mapping of input membership functions to the output membership functions by using the fuzzy inference engine (Mamdani).

Input variable 1 : Output voltage error

Output variable $1: \mathrm{K}_{\mathrm{p}}$

Input variable 2 : Integral of output voltage error

Output variable $2: \mathrm{K}_{\mathrm{i}}$
Table 3. Decision matrix for $K_{P}$

\begin{tabular}{c|c|c|c|c|c|c|c}
\hline CE & NB & NM & NS & ZE & PS & PM & PB \\
\hline NB & NB & NB & NB & NB & NM & NS & ZE \\
\hline NM & NB & NB & NB & NM & NS & ZE & PS \\
\hline NS & NB & NB & NM & NS & ZE & PS & PM \\
\hline ZE & NB & NM & NS & ZE & PS & PM & PB \\
\hline PS & NM & NS & ZE & PS & PM & PB & PB \\
\hline PM & NS & ZE & PS & PM & PB & PB & PB \\
\hline PB & ZE & PS & PM & PM & PB & PB & PB \\
\hline
\end{tabular}

Table 4. Decision matrix for $\mathrm{K}_{\mathrm{i}}$

\begin{tabular}{c|c|c|c|c|c|c|c}
\hline CE & NB & NM & NS & ZE & PS & PM & PB \\
\hline NB & NB & NB & NB & NM & NM & NS & ZE \\
\hline NM & NB & NB & NM & NM & NS & ZE & PS \\
\hline NS & NB & NM & NM & NS & ZE & PS & PM \\
\hline ZE & NM & NM & NS & ZE & PS & PM & PM \\
\hline PS & NM & NS & ZE & PS & PM & PM & PB \\
\hline PM & NS & ZE & PS & PM & PM & PB & PB \\
\hline PB & ZE & PS & PM & PM & PB & PB & PB \\
\hline
\end{tabular}
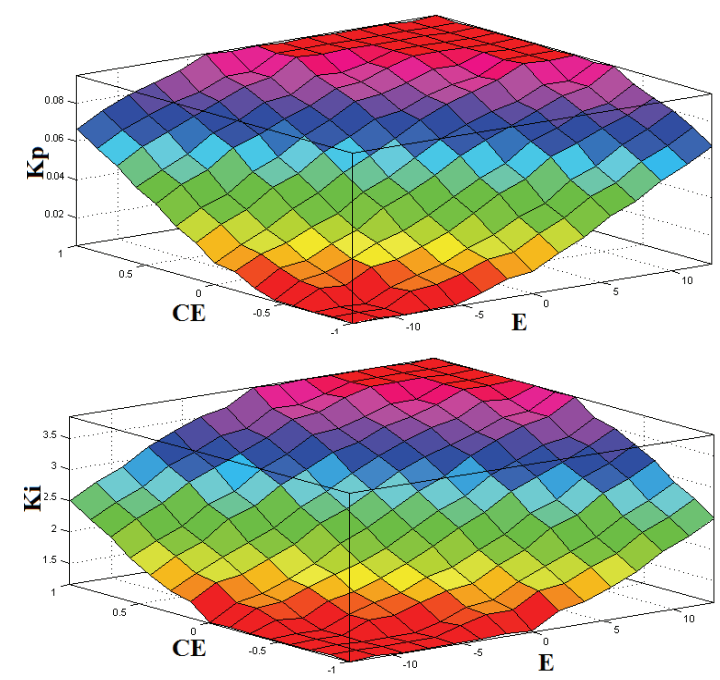

Fig. 3. (d) Fuzzy surface for $K_{p}$ and $K_{i}$

The linguistic variables used are NB-Negative Big; NMNegative Medium; NS-Negative Small; ZE-Zero; PSPositive Small; PM-Positive Big. Table 3 shows the Fuzzy Associative Memory (FAM) table is created in the form of matrix for choosing proper value of $\mathrm{K}_{\mathrm{p}}$ with respect to error and change in error values.

Table 4 depicts the fuzzy associative memory table for the selection of the optimal integral gain of the PI controller depending on inputs such as error and change in error. These Tables 3 and 4 help to produce the favored output based upon the given inputs with the help of the rule base in a fuzzy inference system. Thus, for every occurrence of variations in load or source parameters, $K_{p}$ and $\mathrm{K}_{\mathrm{i}}$ for the proportional controller will be reorganized in correspondence to the changes in input and output parameters.

Fig. 3(d) shows the fuzzy surface for $K_{p}$ and $K_{i}$. The 
system comprises of 49 rules. IF THEN rule type is used in this fuzzy model for source current THD reduction using three level converter.

The rules are explained below,

1) IF CE is negative big and $\mathrm{E}$ is negative big THEN $\mathrm{K}_{\mathrm{p}}$ is negative big.

2) IF $\mathrm{CE}$ is negative big and $\mathrm{E}$ is negative medium THEN $\mathrm{K}_{\mathrm{p}}$ is negative big.

49) IF CE is positive big and $\mathrm{E}$ is positive big THEN $\mathrm{K}_{\mathrm{p}}$ is negative big.

Likewise,

1) IF CE is negative big and $E$ is negative big THEN $K_{i}$ is negative big.

2) IF $\mathrm{CE}$ is negative big and $\mathrm{E}$ is negative medium THEN $\mathrm{K}_{\mathrm{i}}$ is negative big.

49) IF CE is positive big and $\mathrm{E}$ is positive big THEN $\mathrm{K}_{\mathrm{i}}$ is negative big.

The tuned values of PI controller gains' by fuzzy controller are $\mathrm{K}_{\mathrm{p}}=0.04$ and $\mathrm{K}_{\mathrm{i}}=2.5$.

\subsection{Design of hysteresis current controller}

A hysteresis current controller is employed with a closed-loop control system. The switches in the three level converter are examined by error signal e(t). Difference between the generated reference current $\left(i_{\text {ref }}\right)$ and the actual current through the boost inductor $\left(i_{\text {act }}\right.$ ) gives the error signal $\mathrm{e}(\mathrm{t})$. When the error approaches the upper limit of hysteresis band, the transistors are turned off to lower the current. When the error reaches the lower limit, the current is forced to rise. The range of the error signal directly controls the amount of ripple in the working current; this is called the Hysteresis Band. The current is forced to stay within these limits, even while the reference current is changing.

The turn-on and turn-off conditions for switch using hysteresis band are as follows:

- Off state of switch: if (iref - iact) $>\mathrm{HB}$

- On state of switch: if (iref-iact) $<-\mathrm{HB}$

The hysteresis band helps in shaping of source current and reuction of total harmonic distortions in source current. An appropriate bandwidth must be selected in correspondence with the switching capability of the converter. The execution of fixed hysteresis band is uncomplicated and very simple. In this work, the hysteresis band value is 0.01 .

\section{Simulation Analysis}

The PI outer loop voltage controller with Hysteresis inner loop current controller, the fuzzy logic outer loop voltage controller with hysteresis inner loop current controller and the fuzzy-tuned PI outer loop voltage controller with hysteresis current control techniques are simulated through MATLAB Simulink.

\subsection{Simulation results with PI voltage controller and hysteresis current controller}

Fig. 4(a) shows the input voltage and input current waveforms for the PI voltage controller and the hysteresis current controller. The input voltage and input current waveforms are in phase. Therefore, the input power factor is close to unity.

Fig. 4(b) shows the FFT analysis for the PI voltage controller and the hysteresis current controller. The source current total harmonic distortion for the rated load is $3.78 \%$.

Fig. 4(c) shows the regulated output voltage waveform of $48 \mathrm{~V}$ for the PI voltage controller and the hysteresis current controller.

Table 5 shows the performance analysis of the threelevel converter for the PI voltage controller and the hysteresis current controller for various loads. The output voltage is maintained at $48 \mathrm{~V}$ for variations in load. This control technique produces a power factor close to unity.

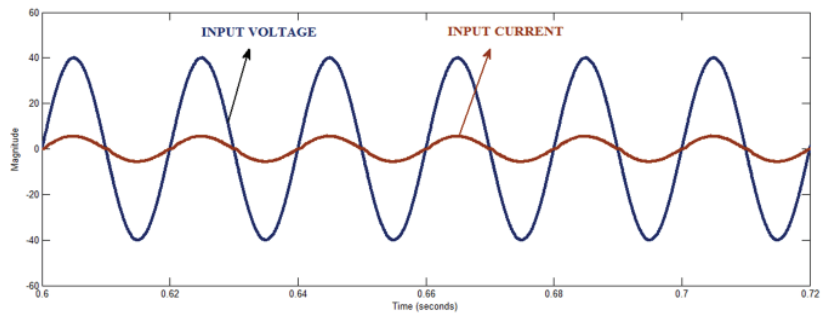

Fig. 4. (a) Input voltage and input current waveforms for PI voltage controller and hysteresis current controller

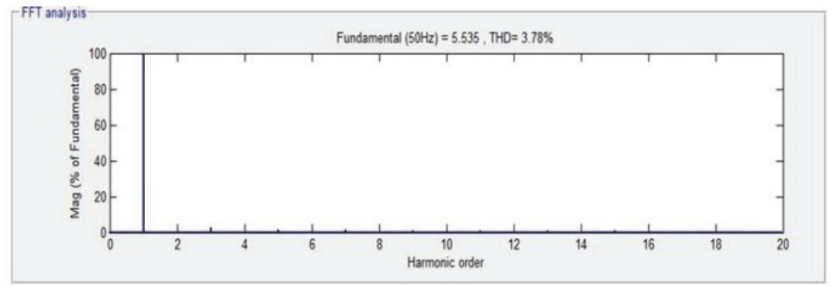

Fig. 4. (b) FFT analysis for PI voltage controller and hysteresis current controller

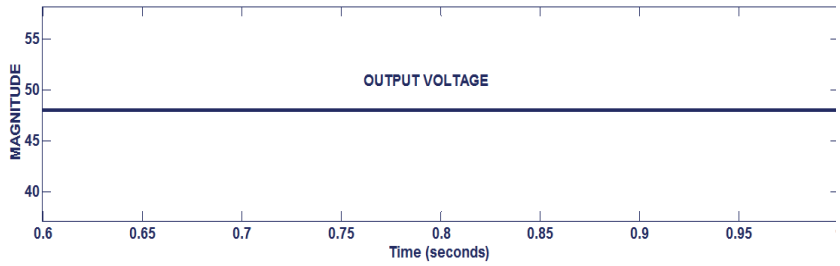

Fig. 4. (c) Output voltage waveform for PI voltage controller and hysteresis current controller 
Table 5. Performance analysis of three-level converter for PI voltage controller and hysteresis current controller

\begin{tabular}{c|c|c|c|c}
\hline $\begin{array}{c}\text { Load } \\
(\%)\end{array}$ & $\begin{array}{c}\text { Output } \\
\text { voltage(V) }\end{array}$ & $\begin{array}{c}\text { Source current } \\
\text { THD(\%) }\end{array}$ & $\begin{array}{c}\text { Input power } \\
\text { factor }\end{array}$ & $\begin{array}{c}\text { Source } \\
\text { current (A) }\end{array}$ \\
\hline 100 & 48 & 3.78 & 0.9997 & 3.92 \\
\hline 75 & 48 & 3.22 & 0.9995 & 2.95 \\
\hline 50 & 48 & 2.83 & 0.9994 & 1.96 \\
\hline 25 & 48 & 3.49 & 0.9987 & 0.98 \\
\hline
\end{tabular}

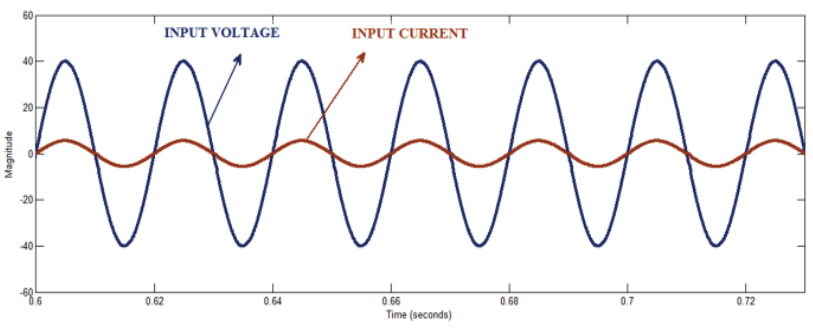

Fig. 4. (d) Input voltage and input current waveforms for fuzzy voltage controller and hysteresis current controller

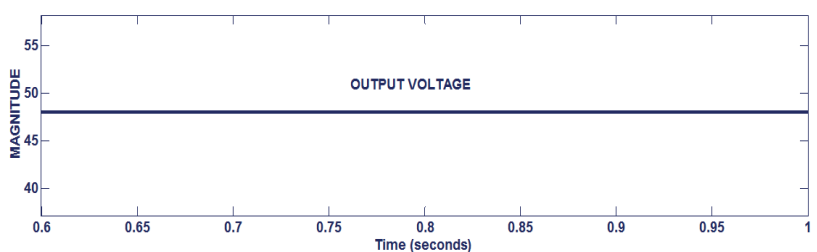

Fig. 4. (e) Output voltage waveform for fuzzy voltage controller and hysteresis current controller

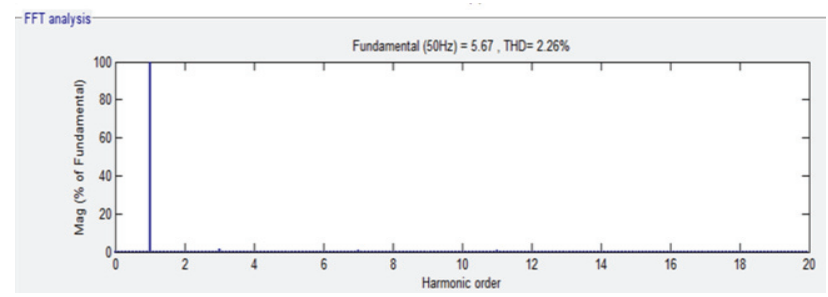

Fig. 4. (f) FFT analysis for fuzzy voltage controller and hysteresis current controller

\subsection{Simulation results with fuzzy logic voltage con- troller and hysteresis current controller}

Fig. 4(d) shows the input voltage and input current waveforms for the fuzzy voltage controller and the hysteresis current controller. Both the source voltage and the source current waveforms are in phase.

Fig. 4(e) shows the regulated output voltage waveform of $48 \mathrm{~V}$ for the fuzzy voltage controller and the hysteresis current controller.

Table 6 shows a performance analysis of the three-level AC-DC converter with the fuzzy voltage controller and the hysteresis current controller. A unity power factor is
Table 6. Performance analysis of three-level converter for fuzzy voltage controller and hysteresis current controller

\begin{tabular}{c|c|c|c|c}
\hline $\begin{array}{c}\text { Load } \\
(\%)\end{array}$ & $\begin{array}{c}\text { Output } \\
\text { voltage(V) }\end{array}$ & $\begin{array}{c}\text { Source current } \\
\text { THD }(\%)\end{array}$ & $\begin{array}{c}\text { Input power } \\
\text { factor }\end{array}$ & $\begin{array}{c}\text { Source } \\
\text { current (A) }\end{array}$ \\
\hline 100 & 48 & 2.26 & 0.9997 & 3.95 \\
\hline 75 & 48 & 2.01 & 0.9998 & 2.95 \\
\hline 50 & 48 & 1.82 & 0.9998 & 1.97 \\
\hline 25 & 48 & 2.10 & 0.9996 & 0.97 \\
\hline
\end{tabular}

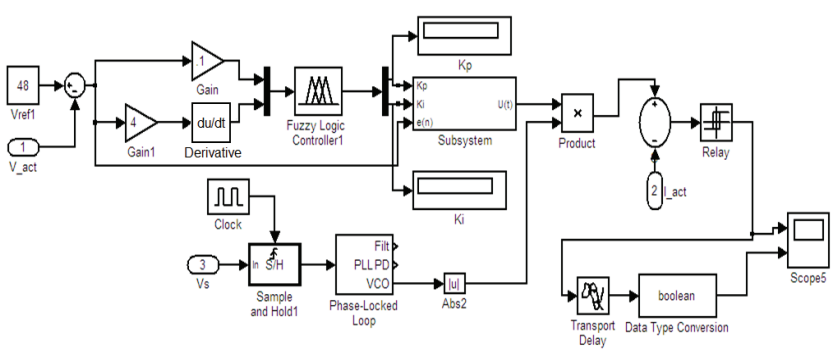

Fig. 4. (g) Simulated circuit diagram of three-level AC-DC converter with fuzzy-tuned PI voltage controller and hysteresis current controller

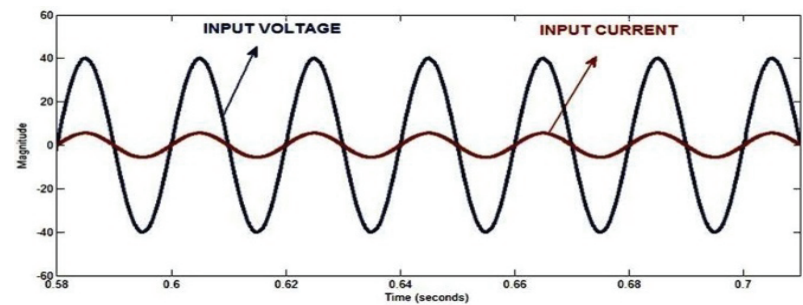

Fig. 4. (h) Input voltage and input current waveforms for fuzzy-tuned PI voltage controller and hysteresis current controller

achieved. Total harmonic distortion is limited to a lower value for wide load variations from $100 \mathrm{~W}$ to $25 \mathrm{~W}$. In addition, the THD at rated power is reduced to $2.26 \%$ (less than 5\%), which is the prescribed IEEE standard.

Fig. 4(f) shows the FFT analysis for the fuzzy voltage controller and the hysteresis current controller. The source current harmonic distortion for the rated load is $2.26 \%$.

\subsection{Simulation results with proposed fuzzy-tuned PI logic voltage controller and hysteresis current controller}

Fig. 4(g) shows the voltage regulator block with the fuzzy-tuned PI logic control. In this control technique, the fuzzy-tuned PI controller is used for voltage regulation and the hysteresis controller is used for input current control. The performance study discloses the remarkable improvement in results using the proposed control topology of fuzzy tuned PI and hysteresis controllers in the three level AC-DC converter.

Fig. 4(h) shows the input voltage and input current 
Table 7. Performance analysis of three-level converter for fuzzy-tuned PI voltage controller and hysteresis current controller

\begin{tabular}{c|c|c|c|c}
\hline $\begin{array}{c}\text { Load } \\
(\%)\end{array}$ & $\begin{array}{c}\text { Output } \\
\text { voltage(V) }\end{array}$ & $\begin{array}{c}\text { Source current } \\
\text { THD(\%) }\end{array}$ & $\begin{array}{c}\text { Input power } \\
\text { factor }\end{array}$ & $\begin{array}{c}\text { Source } \\
\text { current (A) }\end{array}$ \\
\hline 100 & 48 & 0.93 & 1 & 3.97 \\
\hline 75 & 48 & 0.89 & 1 & 2.94 \\
\hline 50 & 48 & 0.78 & 1 & 1.96 \\
\hline 25 & 48 & 1.67 & 1 & 0.98 \\
\hline
\end{tabular}

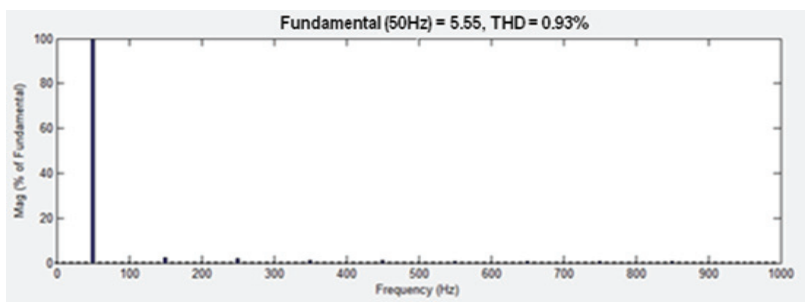

Fig. 4. (i) FFT analysis for fuzzy-tuned PI voltage controller and hysteresis current controller

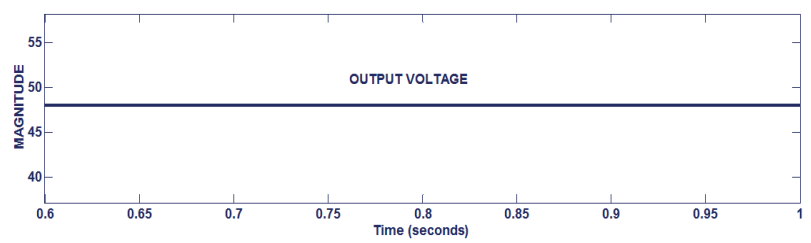

Fig. 4. (j) Output voltage waveform for fuzzy-tuned PI voltage controller and hysteresis current controller

waveforms for the fuzzy-tuned PI voltage controller and the hysteresis current controller. The source current waveform is purely sinusoidal.

Fig. 4(i) shows the FFT analysis for the fuzzy tuned PI voltage controller and the hysteresis current controller. The source current total harmonic distortion is very low at $0.93 \%$.

Fig. 4(j) shows the regulated output voltage waveform of $48 \mathrm{~V}$ for the fuzzy-tuned PI voltage controller and the hysteresis current controller.

Table 7 shows the performance analysis of the three level AC-DC converter with the fuzzy-tuned PI voltage controller and the hysteresis current controller for wide range of load power. The output voltage is well regulated at $48 \mathrm{~V}$ for various loads. This control technique produces a power factor very close to unity and a very low value of source current THD at $0.93 \%$.

\section{Dynamic Response Analysis of the System}

The above analysis illustrates the dynamic response of the three-level converter with the proposed control scheme comprised of the PI-Hysteresis, Fuzzy-Hysteresis and Fuzzy-tuned PI-Hysteresis Controllers as shown in Table 8. It is noted that the output voltage is regulated for all threecontroller combinations, though all of the capacitance
Table 8. Source current THD at various conditions

\begin{tabular}{c|c|c|c}
\hline \multirow{2}{*}{$\begin{array}{c}\text { Controller } \\
\text { combinations }\end{array}$} & $\begin{array}{c}\text { Capacitor } \\
\text { mismatch } \\
\mathrm{C}_{1}=7360 \mu \mathrm{F} \\
\mathrm{C}_{2}=6530 \mu \mathrm{F}\end{array}$ & $\begin{array}{c}\text { Source current THD } \\
\text { variations from } \\
25 \mathrm{~W} \text { to } 100 \mathrm{~W} \\
\text { at } \mathrm{t}=0.8 \mathrm{~s}\end{array}$ & $\begin{array}{c}\text { Supply } \\
\text { variations from } \\
28 \mathrm{~V} \text { to } 36 \mathrm{~V} \text { at } \\
\mathrm{t}=0.6 \mathrm{~s}\end{array}$ \\
\hline PI-Hysteresis & 3.82 & 3.17 & 2.96 \\
\hline Fuzzy-Hysteresis & 2.13 & 2.09 & 2.16 \\
\hline $\begin{array}{c}\text { Fuzzy tuned } \\
\text { PI-Hysteresis }\end{array}$ & 0.94 & 1.77 & 1.23 \\
\hline
\end{tabular}
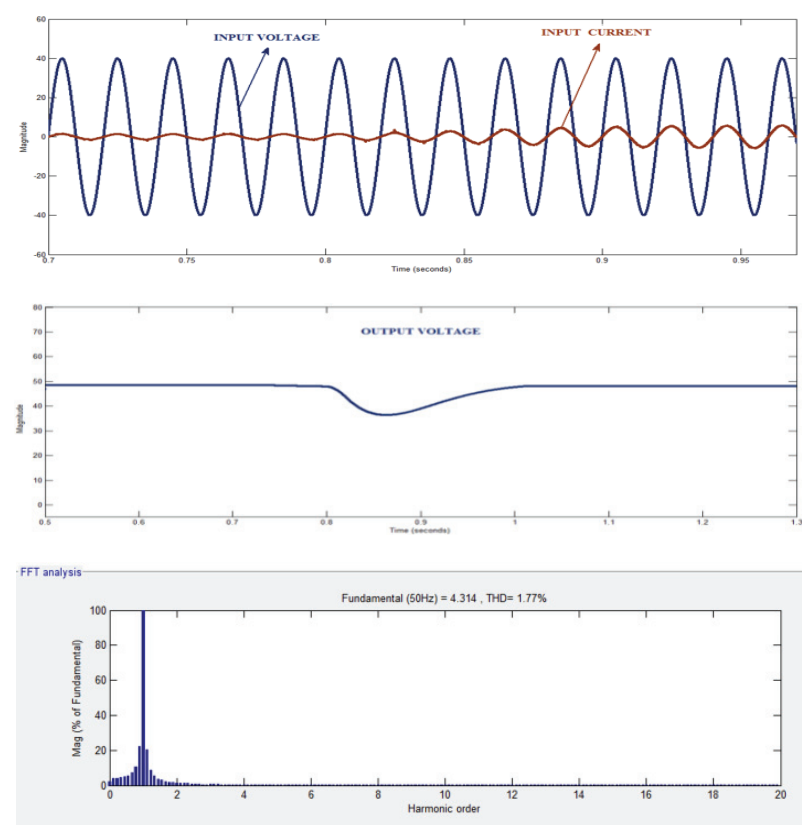

Fig. 5. (a) Simulated results for three-level converter during load change from $25 \mathrm{~W}$ to $100 \mathrm{~W}$ at $0.8 \mathrm{~s}$ with fuzzy-tuned PI voltage controller and hysteresis current controller

values are in a mismatched condition. In addition, the THD values under the rated conditions obtained matched that obtained under the matched capacitance condition. Figs. $5(\mathrm{a})$ and $5(\mathrm{~b})$ show that the output voltage regulation and acceptable harmonic distortion for the sudden change in load from $25 \mathrm{~W}$ to $100 \mathrm{~W}$ during supply voltage variations from $28 \mathrm{~V}$ to $36 \mathrm{~V}$ at $0.6 \mathrm{~s}$ respectively using the fuzzytuned PI voltage controller and the hysteresis current controller. The source current THD value was reduced by $1.77 \%$, which is better than the $3.17 \%$ obtained when using the PI voltage controller and the hysteresis current controller and the $2.09 \%$ obtained with the fuzzy voltage controller and the hysteresis current controller for sudden change in load. For sudden change in supply voltage, THD value obtained is $1.23 \%$, which is better than the $2.96 \%$ of the source current THD obtained when using the PI voltage controller and the hysteresis current controller, as well as better than the source current THD of $2.16 \%$ obtained when using the fuzzy voltage controller and the hysteresis current controller. 

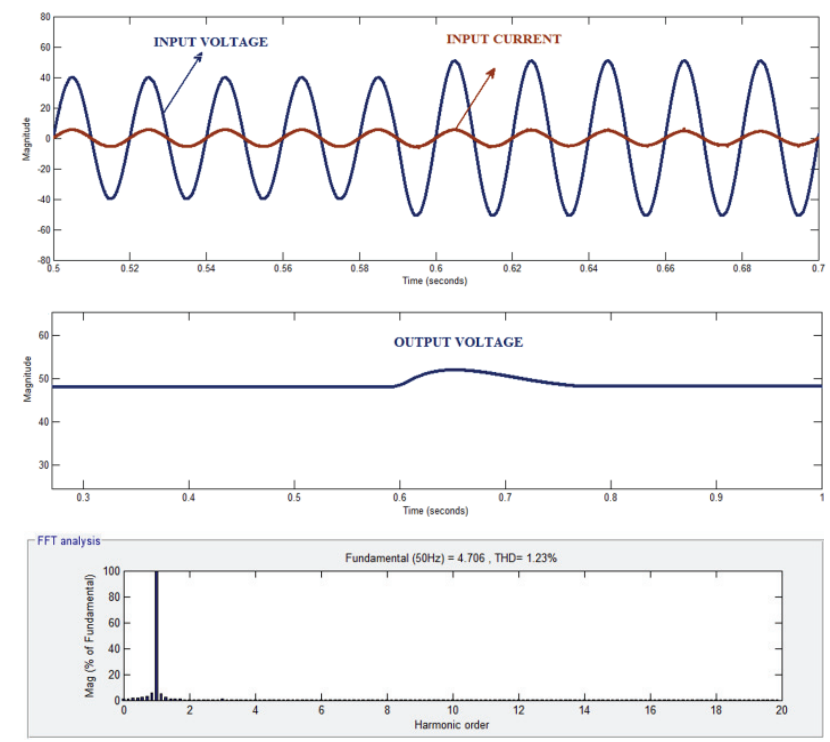

Fig. 5. (b) Simulated results for three-level converter during supply voltage variations from $28 \mathrm{~V}$ to $36 \mathrm{~V}$ at $0.6 \mathrm{~s}$ with fuzzy-tuned PI voltage controller and hysteresis current controller

\section{Fpga Implementation}

Fig. 6(a) shows the proposed schematic diagram of hardware setup of the system. The design of the controllers is implemented using VHDL language on a Xilinx Spartan6 XC6SLX25 FPGA board. Various parameters such as the output voltage $\mathrm{v}_{0}$, the inductor currents $\mathrm{i}_{\mathrm{L}}$ and the source voltage are sensed from the circuit and assigned to ADC as an input. After processing from ADC, digitally converted signals are fed to the FPGA control board. The fuzzy-tuned PI control is used as a voltage controller. The hysteresis control is used as a current controller. On execution of VHDL control program, two gate pulse signals are generated by FPGA. These gate pulse signals are fed to the single phase three level converter via gate driver circuit.

To authenticate the validity of the proposed fuzzy-tuned PI voltage controller and hysteresis current controller, a single-phase three-level AC-DC boost type converter has been built and tested in the laboratory, as shown in Fig. 6(b).

The power semiconductor devices and several components of the three level converter system prototype include an MUR360 input rectifier bridge, IRF250 power switches, a $3 \mathrm{mH}$ boost inductor, a $7000 \mu \mathrm{F}$ output filter capacitor, an FPGA Spartan-6 controller, an HCPL-7840 voltage sensor, a WCS 2705 hall effect current sensor and a $23 \Omega$ load resistor.

Fig. 6(c) shows the practical waveforms of source voltage and source current for rated load power with the fuzzy-tuned PI voltage controller and the hysteresis current controller in three level converter. The power factor and THD are measured with the power quality analyzer shown

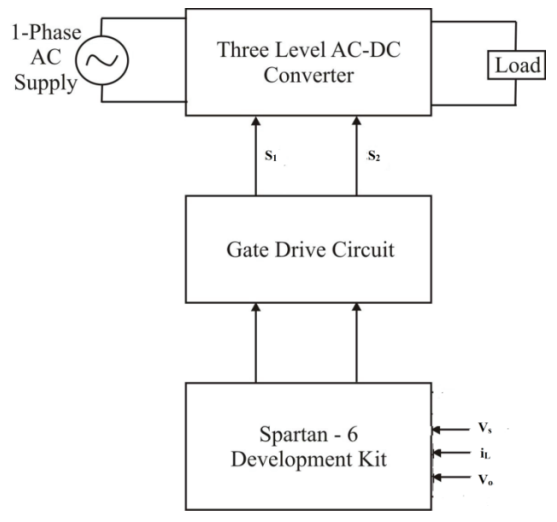

Fig. 6. (a) Block diagram of hardware setup

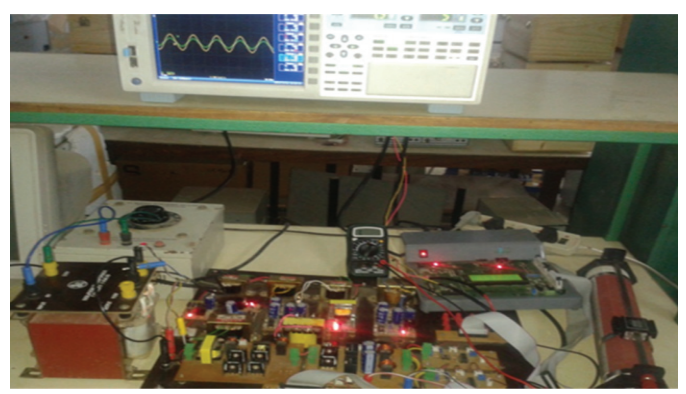

Fig. 6. (b) Hardware setup

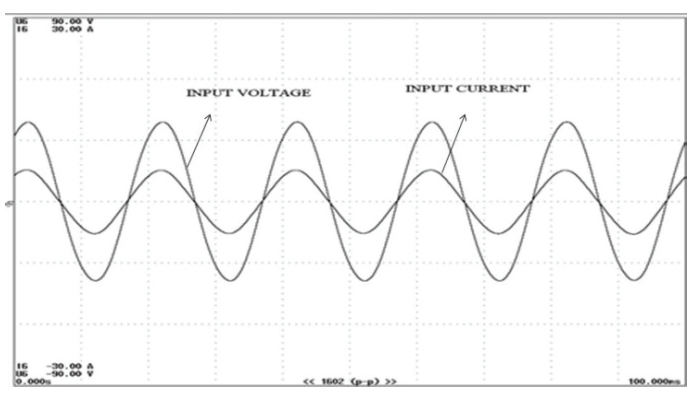

Fig. 6. (c) Experimental input voltage and input current waveforms at rated power with fuzzy-tuned PI voltage controller and hysteresis current controller

\begin{tabular}{|c|c|c|c|c|c|c|c|}
\hline & & Elesent 1 & Elenent 2 & Elenent 3 & Elesent 4 & Element 5 & Elesent 6 \\
\hline Urns & {$\left[\begin{array}{ll}V & ]\end{array}\right]$} & 28.05 & 48.03 & 0.00 & 0.00 & 0.00 & 0.000 \\
\hline Ires & {$\left[\begin{array}{ll}\text { A } & \text { ] }\end{array}\right]$} & 3.9690 & 1.9421 & 0.0000 & 0.0000 & 0.0000 & 0.0000 \\
\hline$p$ & {$\left[\begin{array}{ll}* & ]\end{array}\right]$} & 111.88 & 93.28 & -0.00 & $0.0000 k$ & $0.0000 \mathrm{k}$ & 0.00 \\
\hline$s$ & [VA ] & 111.91 & 100.45 & 0.00 & $0.0000 k$ & $0.0000 \mathrm{k}$ & 0.00 \\
\hline$\lambda$ & [ ] & 0.9999 & 0.8107 & Error & Error & Error & Error \\
\hline Uthd & {$\left[\begin{array}{ll}x & ]\end{array}\right]$} & 0.409 & 1.189 & 0.0000 & 0.0000 & 0.0000 & 0.0000 \\
\hline It the & {$\left[\begin{array}{ll}x & ]\end{array}\right]$} & 1.351 & 1.185 & 0.0000 & 0.0000 & 0.0000 & 0.0000 \\
\hline
\end{tabular}

Fig. 6. (d) Power quality measurements in element 1 for rated load power with fuzzy-tuned PI voltage controller and hysteresis current controller

in Fig. 6(d). Based on this Fig. 6(d), the input power factor is 0.9999 and the source current THD is $1.351 \%$. 


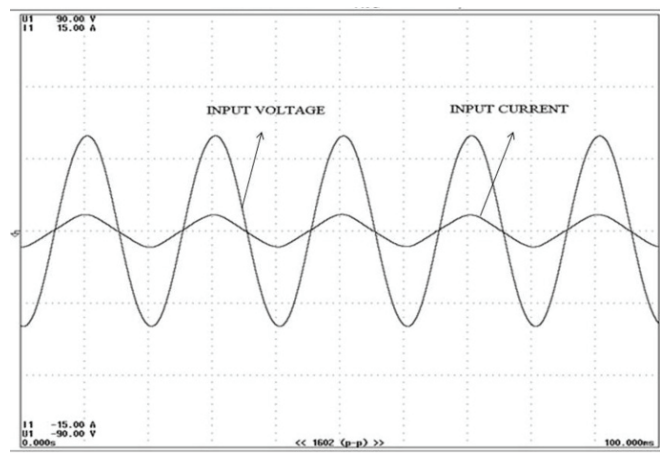

Fig. 6. (e) Experimental input voltage and input current waveforms at $25 \%$ of load power with fuzzy-tuned PI voltage controller and hysteresis current controller

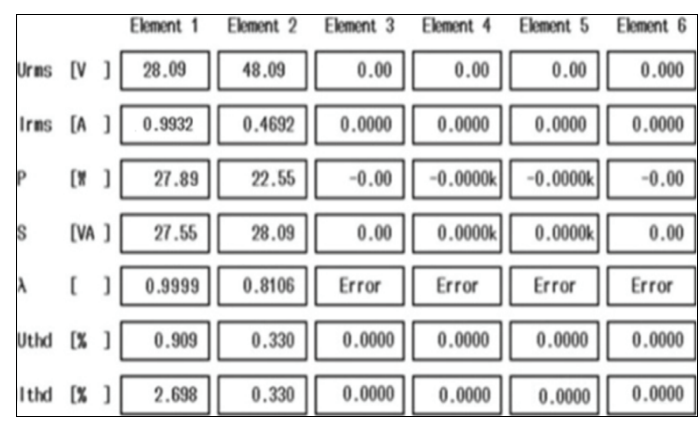

Fig. 6. (f) Power quality measurements in element 1 for $25 \%$ of load power with fuzzy-tuned PI voltage controller and hysteresis current controller

Fig. 6(e) shows the practical waveforms of source voltage and source current for $25 \%$ of load power with the fuzzy-tuned PI voltage controller and the hysteresis current controller for three level converter. The power factor and THD are measured with the power quality analyzer shown in Figure 6f. Based on this figure 6f, the input power factor is 0.9999 and the source current THD is $2.698 \%$.

\section{Comparative Analysis}

Fig. 7(a) shows the simulation results of the source current total harmonic distortion comparison curve for PI, Fuzzy and Fuzzy-tuned PI along with the hysteresis current controller. The proposed fuzzy-tuned PI controller-based single-phase AC-DC three-level converter provides better results compared with the PI and fuzzy voltage controller. The THD of the fuzzy-tuned PI voltage controller and the hysteresis current controller is $0.93 \%$. This value is lower than the IEEE-516 standard.

Fig. 7(b) shows the simulation results of the power factor comparison curve for PI, fuzzy and fuzzy-tuned PI along with the hysteresis current controller. The proposed fuzzy-tuned PI controller-based single-phase AC-DC threelevel converter provides better results compared with the PI and fuzzy voltage controller. The power factor of the

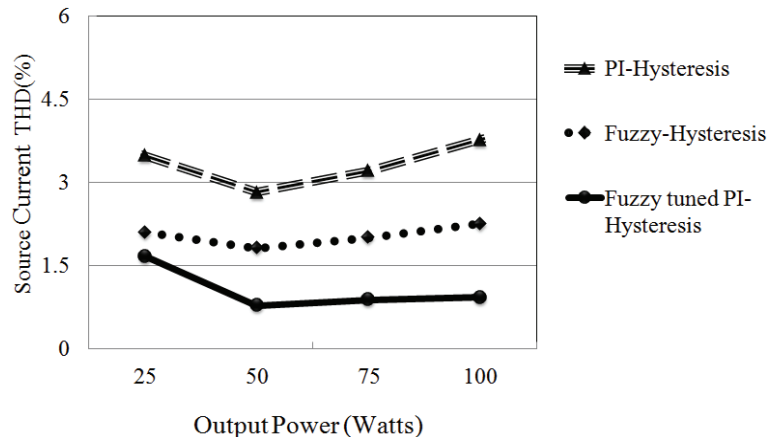

Fig. 7. (a) Simulation result with comparison of THD value

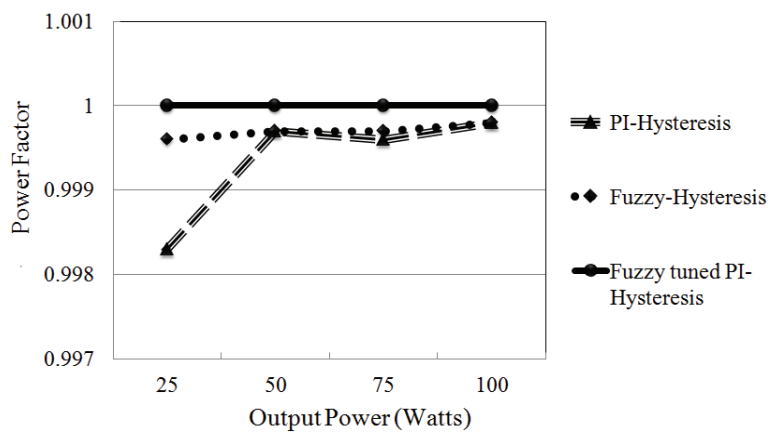

Fig. 7. (b) Simulation result with comparison of power factor value

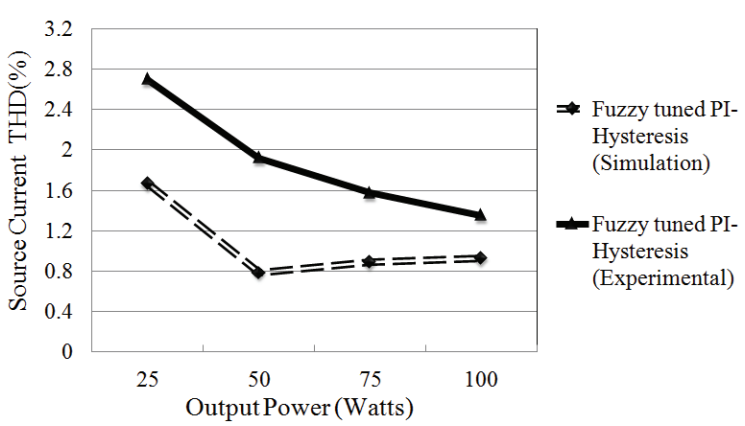

Fig. 7. (c) Variations of source current THD for output power

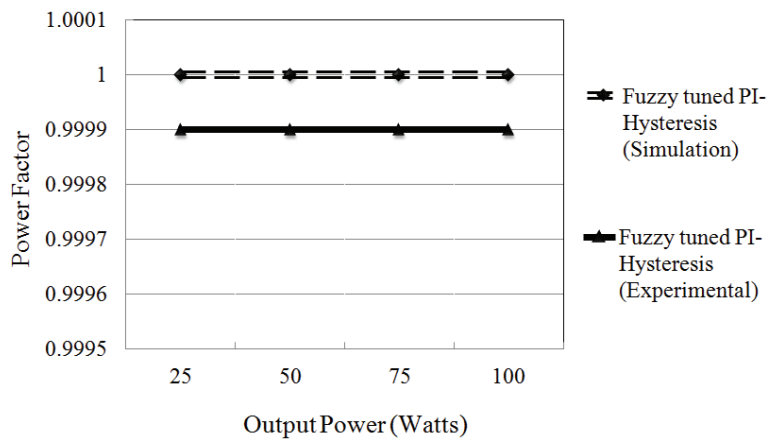

Fig. 7. (d) Variations of input power factor for output power

fuzzy-tuned PI voltage controller and the hysteresis current controller is 0.9999 , which is close to unity for wide variations of load. 
Fig. 7(c) shows the variations of source current THD value for output power. The simulation results of the THD values of the fuzzy-tuned PI voltage controller and the hysteresis current controller is $0.93 \%$. The THD experimental result of the three level converter with fuzzy-tuned PI voltage controller and hysteresis current controller is $1.351 \%$. This value is lower than the IEEE516 standard.

Fig. 7(d) shows Variations of input Power Factor for output power. The simulation results of the power factor values of the fuzzy-tuned PI voltage controller and the hysteresis current controller is 1 . The power factor of the experimental result with the fuzzy-tuned PI voltage controller and the hysteresis current controller is 0.9999 .

\section{Conclusions}

This paper dealt with the design and implementation of closed-loop controllers for a single-phase AC-DC threelevel converter for power quality improvement under $\mathrm{AC}$ supply. The closed-loop control for the converters consisted of two loops: an outer voltage controller and an inner current controller. An HCC controller was used as the inner current controller. For the outer voltage controllers, three controllers were designed - a PI controller, a fuzzy logic controller and a fuzzy-tuned PI controller. The performance of the entire system was simulated and compared for the three different voltage controllers. The fuzzy-tuned PI voltage controller and the hysteresis current controller were implemented in a FPGA-based hardware platform. The comparison revealed that the fuzzy-tuned PI voltage controller with the hysteresis current controller showed better performance, with a lower source current THD of $0.93 \%$ in the simulation and $1.351 \%$ in the experiment, along with a power factor close to unity without any source side filter. It was also able to achieve an input current THD of less than $5 \%$ and a power factor close to unity for wide variations of load and for sudden disturbances in load and supply voltage. This source current THD is lower than the IEEE-519 standard. The applications of this three level converter are special machine drives, grid connected applications, battery chargers, fuell cell applications.

\section{References}

[1] M. M. Jovanovic and D. E. Crow, "Merits and limitations of full bridge rectifier with LC filter in Meeting IEC1000-3-2 Harmonic Limit Specifications," IEEE Trans. Ind. Applicat., vol. 33, pp. 551-557, Mar./Apr. 1997.

[2] R. Redl, "An economical single-phase passive powerfactor corrected rectifier: Topology, operation, extensions, and design for compliance," in Proc. IEEE Appl. Power Electron. Conf. (APEC), 1998, pp.
454-460.

[3] A. R. Prasad, P. D. Ziogas, and S. Manias, "A novel passive wave shaping method for single phase diode rectifiers," IEEE Trans. Ind. Electron., vol. 37, pp. 521-530, Dec. 1990.

[4] Limits for Harmonic Current Emissions (Equipment Input Current $<16$ A per Phase), IEC 1000/3/2 Int. Std., 1995.

[5] "IEEE 519 Recommended practices and requirements for harmonic control in electrical power systems," Tech. Rep., IEEE Industry Applications Soc./Power Engineering Soc., 1993.

[6] B. Singh, B. N. Singh, A. Chandra, K. Al-Haddad, A. Pandey and D. P. Kothari, "A Review of Single-Phase Improved Power Quality AC-DC Converters," IEEE Trans. on Industrial Electronics, vol. 50, no. 5, pp. 962-981, Oct. 2003.

[7] J. C. Crebier, B. Revol, and J. P. Ferrieux, "BoostChopper-Derived PFC Rectifiers: Interest and Reality", IEEE Trans. on Industrial Electronics, vol.52, no. 1, pp. 36-45, Feb. 2005.

[8] S. Moon, L. Corradini and D. Maksimovic, "Autotuning of Digitally Controlled Boost Power Factor Correction Rectifiers," IEEE Trans. On Power Electronics, vol. 26, no. 10, pp. 3006- 018, Oct. 2011.

[9] M. Chen and J. Sun, "Feedforward Current Control of Boost Single- Phase PFC Converters", IEEE Trans. on Power Electronics, vol. 21, no. 2, pp.338-345, March 2006.

[10] H. C. Chen, H. Y. Li and R. S. Yang, "Phase Feedforward Control of Single-Phase PFC BoostType SMR", IEEE Trans. on Power Electronics, vol. 24, no. 5, pp. 1428-1432, May 2009.

[11] H. C. Chang, and C. M. Liaw, "An Integrated Driving/Charging Switched Reluctance Motor Drive Using Three-Phase Power Module," IEEE Trans.on Industrial Electronics, vol. 58, no. 5, pp. 1763-1775, 2011.

[12] J. Y. Chai, Y. H. Ho, Y. C. Chang and C. M. Liaw, "On Acoustic-Noise-Reduction Control Using Random Switching Technique for Switch-Mode Rectifiers in PMSM Drive," IEEE Trans. on Industrial Electronics, vol. 55, no. 3, pp.2576-2584, Sep. 2008.

[13] L. S. Yang, T. J. Liang, H. C. Lee and J. F. Chen, "Novel High Step-Up DC-DC Converter With Coupled-Inductor and Voltage-Doubler Circuits", IEEE Trans. on Industrial Electronics, vol. 58, no. 9, pp. 4196-4206, Sep.2011.

[14] W. Li and X. He, "Review of Nonisolated HighStep-Up DC/DC Converters in Photovoltaic GridConnected Applications", IEEE Trans.on Industrial Electronics, vol. 58, no. 4, pp. 1239-1250, April 2011.

[15] A. Shahin, M. Hinaje, J. P. Martin, S. Pierfederici, S. Rael and B. Davat, "High Voltage Ratio DC-DC Converter for Fuel-Cell Applications," IEEE Trans. on Industrial Electronics, vol. 57, pp. 3944-3955, Dec. 
2010.

[16] M. H. Todorovic, L. Palma, and P. N. Enjeti, "Design of a Wide Input Range DC-DC onverter With a Robust Power Control Scheme Suitable for Fuel Cell Power Conversion," IEEE Trans. on Industrial Electronics, vol. 55, no. 3, pp. 1247-1255, March 2008.

[17] J. M. Kwon, B. H. Kwon and K. H. Nam, “ThreePhase Photovoltaic System with Three-Level Boosting MPPT Control," IEEE Trans. on Power Electronics, vol. 23, pp. 2319-2327, Sep. 2008.

[18] V. Yaramasu, and B. Wu, "Three-Level Boost Converter Based Medium Voltage Megawatt PMSG Wind Energy Conversion Systems," Energy Conversion Congress and Exposition (ECCE), pp. 561-567, 2011

[19] M. T. Zhang, Y. Jiang, F. C. Lee, and M. M. Jovanovic, "Single-phase three-level boost power factor correction converter," in IEEE APEC,95, pp. 434-439, 1995.

[20] R. Greul, S. D. Round and J. W. Kolar, "The DeltaRectifier: Analysis, Control and Operation" IEEE Trans. on Power Electronics, vol. 21, no. 6, pp. 16371648, Nov. 2006.

[21] B. R. Lin and H. H. Lu, "Single-Phase Power-Factor Correction AC/DC Converters with Three PWM Control Schemes" IEEE Trans. on Aerospace and Electronic Systems, vol. 36, no. 1, pp. 189-200, Jan. 2000.

[22] B. R. Lin and H. H. Lu, "A Novel PWM Scheme for Single-Phase Three-Level Power-Factor-Correction Circuit" IEEE Trans. on Industrial Electronics, vol. 47, pp. 245-252, Apr. 2000.

[23] Hung-Chi Chen and Jhen-Yu Liao, "Multiloop Interleaved Control for Three-Level Switch-Mode Rectifier in AC/DC Applications" IEEE Trans. on Industrial Electronics, Vol.61, No.7, July 2014.

[24] M.Rajesh and B.Singh, "Analysis, design and control of single phase three level power factor correction rectifier fed switched reluctance motor drive" IET power Electronics, vol.7, no.6, pp.1499-1508, June 2014.

[25] N. Senthil Kumar, V. Sadasivam, H. M. Asan Sukriya "A Comparative Study of PI, Fuzzy, and ANN Controllers for Chopper-fed DC Drive with Embedded Systems Approach", Electric Power Components and Systems, vol. 36, no. 7, 2008, pp. 680-695

[26] Prema Kannan, Senthil Kumar Natarajan, and Subhransu Sekhar Dash, "Design and Implementation of Fuzzy Logic Controller for Online Computer Controlled Steering System for Navigation of a Teleoperated Agricultural Vehicle," Mathematics problems in Engineering, Hindawi Publishing Corporation, Volume 2013, Article ID 590861,10 pages.

[27] A. Kessal, L. Rahmani, M. Mostefai, j. Gaubert, "Power factor correction based on fuzzy logic controller with fixed switching frequency" Electronics and Electrical Engineering - Kaunes: Technologija,
2012, no. 2(118), pp. 67-72.

[28] Sang-wha seo, Han ho choiad and yong Kim, 'TakagiSugeno fuzzy model based approach to robust control of boost DC-DC converters", Journal of Electrical Engineering and Technology, vol. 10, no. 3, pp. 925934, may 2015.

[29] Hak-Seung Ro, Kyoung -GuLee, Hae-Guang Jeong and Kyo-Beun Lee, "Torque ripple minimization scheme using Torque sharing function based fuzzy logic control for a switched motor", Journal of Electrical Engineering and Technology, vol.10, no.1, pp. 118-127, January 2015.

[30] K. Prema, N. Senthil Kumar and Subhransu Sekhar Dash, "Online control of DC motors using fuzzy logic controller for remote operated robots", Journal of Electrical Engineering \& Technology, vol.9, no.1, pp. 352-362, Jan 2014.

[31] H. C. Lee. "Robust adaptive fuzzy control by backstepping for a class of MIMO nonlinear systems", IEEE Trans. on Fuzzy Systems, vol.19 (2): 265-275, 2011.

[32] Y. P. Pan, J. E. Meng, D. P. Huang, and Q. R. Wang. "Adaptive fuzzy control with guaranteed convergence of optimal approximation error", IEEE Trans. on Fuzzy Systems, pp.807-818, 2011.

[33] Manjun Cai and Yue Wang "A fuzzy-PI hybrid controller based on a disturbance Observer", IEEE Trans. Ninth International Conference on Natural Computation (ICNC) on 2013.

[34] Sima Seidi Khorramabadi and Alireza Bakhshai," Critic-based self-tuning PI structure for active and reactive power control of VSCS in microgrid systems", IEEE Trans. on smart grid, pp. 1949-3053, 2014.

[35] A. Balestroni, A. Landi, and L. Sani, "CUK converter global control via fuzzy logic and scaling factors," IEEE Trans. Ind. Applications, vol. 38, no. 2, pp. 406413, Mar./Apr. 2002.

[36] Jin Zhao and Bimal K.Bose, "Evaluation of membership functions for fuzzy logic controlled induction motor drive", in IEEE IECONOZ, pp.229234, 2002.

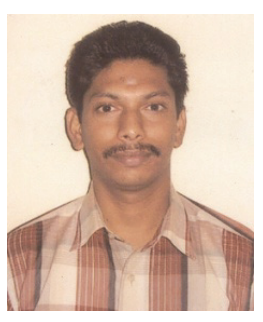

J. Gnanavadivel He obtained his B.E. degree in Electrical and Electronics Engineering from Madras University, Chennai, in 1999, M.E. degree in Power Electronics and Drives from Bharathidhasan University, Trichy, in 2000. He has published seven papers in International Journals, 23 papers in International conferences and 10 text books. His field of interests mainly concerned with Power Electronics and Drives, Power quality issues in AC-DC power converters and intelligent controllers. 


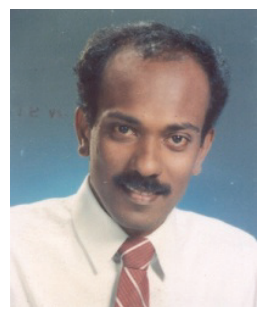

N. Senthil Kumar He obtained his B.E. degree in Electronics and Communication Engineering from Madurai Kamaraj University, Madurai, in 1988, M.E. degree in Electronics Engineering from Anna University, Chennai, in 1991 and Ph.D. in Electronics and Computer Science engineering from Manonmaniam Sundaranar University, Tirunelveli in 2008. He has published a paper in National Journal and 29 papers in International Journals. His interests include intelligent control, fuzzy logic and neural networks. Dr. N. Senthil Kumar is a member of Institutions of Engineers, System Society of India and Indian Society for Technical Education.

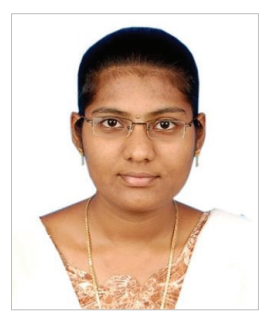

P. Yogalakshmi She received her B.E. degree in Electronics and Instrumentation Engineering from Anna University, Chennai in 2013 and M.E. degree in Power Electronics and Drives from Anna University, Chennai in 2015. She has published one paper in International Journal and two International conference papers. Her field of interests mainly concerned with Power Electronics converters and intelligent controllers. 